\title{
Acute Pancreatitis and Posterior Reversible Encephalopathy Syndrome: A Case Report
}

\author{
Pancreatite Aguda e Síndrome de Encefalopatia \\ Posterior Reversível: Relato de um Caso
}

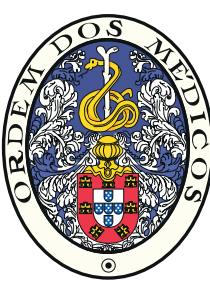

\author{
Vítor Magno PEREIRA ${ }^{1}$, Luís Marote CORREIA², Tiago RODRIGUES ${ }^{3}$, Gorete Serrão FARIA ${ }^{1}$ \\ Acta Med Port 2016 Sep;29(9):567-571 - http://dx.doi.org/10.20344/amp.7368
}

\begin{abstract}
The posterior reversible encephalopathy syndrome is a neurological syndrome characterized by headache, confusion, visual disturbances and seizures associated with identifiable areas of cerebral edema on imaging studies. The authors report the case of a man, 33 years-old, leukodermic with a history of chronic alcohol and tobacco consumption, who is admitted to the emergency department for epigastric pain radiating to the back and vomiting with about six hours of evolution and an intense holocranial headache for two hours. His physical examination was remarkable for a blood pressure of $190 / 100 \mathrm{mmHg}$ and tenderness in epigastrium. His analytical results revealed emphasis on amylase $193 \mathrm{U} / \mathrm{L}$ and lipase $934 \mathrm{U} / \mathrm{L}$. During the observation in the emergency department, he presented a generalized tonic-clonic seizure. Abdominal ultrasonography was performed and suggestive of pancreatitis without gallstones signals. Head computed tomography showed subarachnoid haemorrhage and a small right frontal cortical haemorrhage. The brain magnetic resonance imaging done one week after admission showed areas of a bilateral and symmetrical T2 / FLAIR hyperintensities in the subcortical white matter of the parietal and superior frontal regions, suggesting a diagnosis of posterior reversible encephalopathy syndrome. Abdominal computed tomography (10 days after admission) demonstrated a thickened pancreas in connection with inflammation and two small hypodense foci in the anterior part of the pancreas body, translating small foci of necrosis. The investigation of a thrombophilic defect revealed a heterozygous G20210A prothrombin gene mutation. The patient was discharged without neurological sequelae and asymptomatic. The follow-up brain magnetic resonance imaging confirmed the reversal of the lesions, confirming the diagnosis.
\end{abstract}

Keywords: Alcoholism/complications; Brain Edema; Pancreatitis, Alcoholic; Posterior Leukoencephalopathy Syndrome.

\section{RESUMO}

A síndrome de enfalopatia posterior reversível é uma síndrome neurológica caracterizada por cefaleias, confusão, alterações visuais e convulsões associada a áreas de edema cerebral identificável em exames de neuroimagem. Os autores relatam o caso de um homem, 33 anos, leucodérmico, com história de alcoolismo e tabagismo crónico, que recorre ao serviço de urgência por epigastralgia em cinturão e vómitos com cerca de seis horas de evolução e cefaleia holocraneana intensa há duas horas. Ao exame objectivo, apresentava tensão arterial de 190/100 mmHg e empastamento no epigastro. Analiticamente, amilase 193 U/L e lipase 934 U/L. Durante a observação no serviço de urgência, apresentou uma crise tónico-clónica generalizada. A ecografia abdominal realizada foi sugestiva de pancreatite, sem sinais de litíase biliar. A tomografia computorizada crânio-encefálica demonstrou hemorragia subaracnoideia e pequena hemorragia cortical frontal direita. A ressonância magnética nuclear crânio-encefálica realizada uma semana após a admissão revelou áreas de hipersinal T2/FLAIR bilaterais e simétricas na substância branca subcortical das regiões parietais e frontais superiores, sugerindo o diagnóstico de síndrome de enfalopatia posterior reversível. Na tomografia computorizada abdominal (10 dias após a admissão) visualizou-se pâncreas espessado, em relação com processo inflamatório e dois pequenos focos hipodensos na parte anterior do corpo, traduzindo pequenos focos de necrose. A investigação de defeitos trombofílicos revelou uma mutação do gene G20210A da protrombina em heterozigotia. O doente teve alta sem sequelas neurológicas, e assintomático. A ressonância magnética nuclear crânio-encefálica de controlo confirmou a reversão das lesões, confirmando o diagnóstico.

Palavras-chave: Alcoolismo/complicações; Edema Cerebral; Pancreatite Alcoólica; Síndrome de Enfalopatia Posterior Reversível.

\section{INTRODUCTION}

Originally named in a 1996 case series, the reversible posterior leukoencephalopathy syndrome or posterior reversible encephalopathy syndrome (PRES) is characterized by the clinical findings of headache, altered mental functioning, seizures, and loss of vision associated with symmetric and bilateral cerebral edema, most commonly in the occipito-parietal regions, on the neuroimaging studies. ${ }^{1}$ Several conditions have been associated with PRES. The most well-documented are hypertension, eclampsia and immunosuppressive therapy. There is also a frequent association with cytotoxic treatments, autoimmune diseases and infection/sepsis. ${ }^{2}$ There are as well numerous associa- tions rarely or anecdotally reported. In the context of acute pancreatitis there have been reported only eight cases, ${ }^{3-10}$ six of them available on PubMed/MEDLINE database. ${ }^{3-5,7-9}$ With early diagnosis and prompt treatment, the syndrome is usually fully reversible. ${ }^{2}$

\section{CLINICAL FINDINGS}

The subject of this report is a 33-year-old leukodermic male, single, born and resident in Funchal, Madeira Island and employed as a construction worker. He disclosed a history of chronic alcoholism with an approximate consumption of $100 \mathrm{~g}$ of alcohol per day during the week

\footnotetext{
1. Serviço de Gastrenterologia. Hospital Central do Funchal. Funchal. Portugal.

2. Serviço de Medicina Interna. Hospital Central do Funchal. Funchal. Portugal.

3. Serviço de Neurorradiologia. Hospital Central do Funchal. Funchal. Portugal.

$\triangle$ Autor correspondente: Vítor Magno Pereira. magnovitorp@gmail.com

Recebido: 05 de janeiro de 2016 - Aceite: 16 de maio de 2016 | Copyright $\odot$ Ordem dos Médicos 2016
} 
and about $150 \mathrm{~g}$ of alcohol per day in the weekend. He was an active tobacco smoker with a chronic consumption of 10 pack-year units and smoked cannabis about twice per month, denying any other history of drug use. He had no chronic medication and no drug or food allergies. No other personal relevant background was found. As family history is concerned, his mother had a diagnosis of arterial hypertension, currently controlled with chronic medication and his father was diagnosed with colorectal adenocarcinoma at 57 years-old.

The patient presented to the emergency department (ED) of our hospital in August 2015 with an epigastric pain with dorsal irradiation, with an intensity $8 / 10$ of sudden onset and with six hours of evolution. He complained of nausea and vomit starting a few minutes after the abdominal pain and a holocranial intense headache with two hours of evolution and progressive worsening.

On physical examination he was confused but cooperative, with a Glasgow coma scale (GCS) of 14 (E4V4M6). His temperature was $36.4^{\circ} \mathrm{C}$, blood pressure of $190 / 100 \mathrm{mmHg}$, heart rate (HR) of 54 beats per minute (bpm) and a respiratory rate (RR) of 24 cycles per minute (cpm) at room air with $\mathrm{SpO} 2$ (peripheral oxygen saturation) of $99 \%$. Auscultation revealed no abnormalities. In abdominal examination, bowel sounds were absent and tenderness in epigastrium was evident; there was pain on pressuring the epigastrium but no signs of peritoneal irritation.

While on observation, he had a generalized tonic-clonic seizure that lasted about 30 seconds, resolving immediately after the injection of $10 \mathrm{mg}$ of intravenous (IV) diazepam.

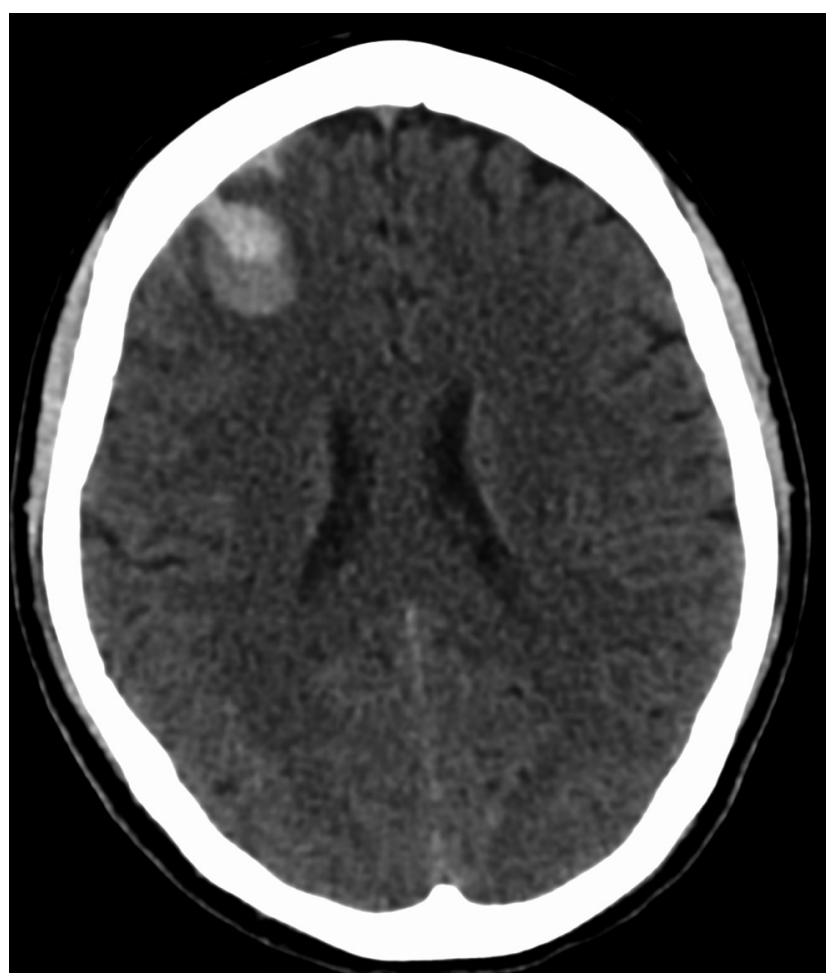

Figure 1 - Initial CT scan showing an acute hematoma in the right frontal lobe and small amount of blood in the adjacent subarachnoid space
Likewise, $500 \mathrm{mg}$ of phenytoin were infused. In the first 24 hours, another two tonic-clonic seizures were documented.

\section{DIAGNOSTIC FOCUS AND ASSESSMENT}

Complete blood count revealed leucocytosis $(24,000 /$ $\mu \mathrm{L}$ ) with neutrophilia (91.6\%), a normal haemoglobin and platelet count. Blood chemistry confirmed elevation of serum amylase (193 U/L; reference range $(R R):<46 \mathrm{U} / \mathrm{L})$, lipase (934 U/L; RR: < 51) and glucose (156 mg/dL). The levels of liver transaminases, bilirubin, urea, creatinine, lactate dehydrogenase (LDH) and C-reactive protein (CRP) were normal.

After the first seizure, he was supplemented with oxygen and an arterial blood gas analysis was done (at $\mathrm{FiO} 2$ 40\%) that revealed a severe metabolic acidemia with hyperlactacidemia and hypokalemia $\left(\mathrm{pH}\right.$ 6.98, $\mathrm{pCO}_{2} 41$ mmHg, pO2 235 mmHg, HCO3 - 10.5 mmol/L, lactate 18 $\mathrm{mmol} / \mathrm{L})$.

The chest radiography showed no abnormalities. The abdominal ultrasound revealed a decreased diffuse parenchymal echogenicity of the pancreas and pancreatic body thickening, compatible with edema which correlates with pancreatitis; there were no signs of gallstones.

The initial head CT (Fig. 1) revealed a small acute lobar haemorrhage in the right frontal lobe associated with a minor amount of blood in the surrounding cortical sulci. The MRI of the brain (Fig. 2), performed seven days later, showed a slight increase in the dimensions of the right frontal lobe subacute haemorrhage and of the surrounding edema but without significant mass effect. There were also

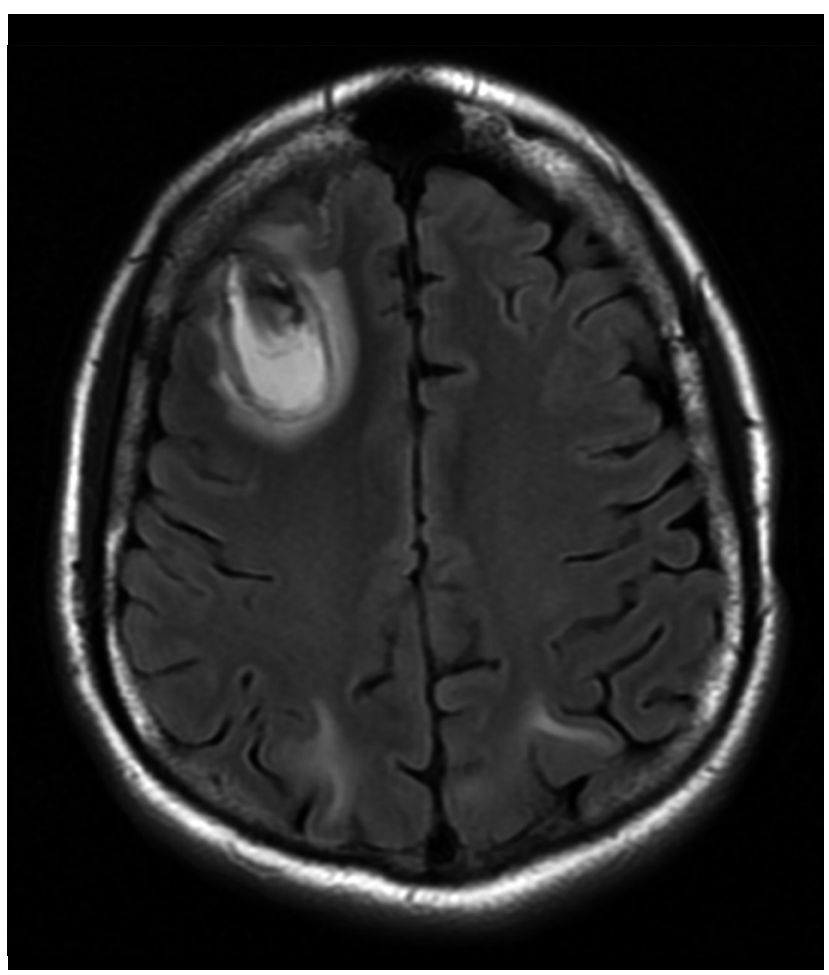

Figure 2 - Initial MRI scan (7 days). Axial T2-FLAIR images revealing bilateral and symmetric subcortical hyperintensities on the parietal lobes. There is also a slight growth of the subacute hemorrhage in the right frontal lobe. 
bilateral and symmetric T2/FLAIR hyperintense lesions in the subcortical white matter of the parietal and frontal lobes, without diffusion restriction, contrast enhancement or mass effect, suggesting posterior reversible encephalopathy syndrome (PRES).

According to the revised Atlanta classification system, the acute pancreatitis was classified as interstitial edematous and moderately severe. The Acute Physiology and Chronic Health Evaluation II (APACHE II) score was 17 points and the Bedside Index for Severity in Acute Pancreatitis (BISAP) score was three points.

Consequently, the patient was admitted to the Intensive Care Unit (ICU).

\section{THERAPEUTIC FOCUS AND ASSESSMENT}

Our patient was treated with supportive care: nil per os was instituted and the patient started vigorous IV hydration with normal saline and lactated Ringer's solution; analgesia with pethidine; anti-hypertensive therapy with IV clonidine titrated according the blood pressure; and anti-convulsive with IV phenytoin.

After 24 hours, the blood pressure had stabilized around $140 \mathrm{mmHg}$ systolic and $90 \mathrm{mmHg}$ diastolic, the mental status improved, and neither neurological deficits nor symptoms of alcohol withdrawal were present (IV tiapride and thiamine was administered daily from admission due to his regular heavy alcohol consumption). Sinus bradycardia was observed but it resolved after phenytoin was withdrawn and levetiracetam added. Although bilateral pleural effusion was evident on plain chest radiographs there were no acute distress respiratory syndrome radiologic signs. On the third day, enteric nutrition was initiated and the IV hydration and analgesia were abridged, and oxygen supplementation was suspended.

Once stable, the patient was transferred to the gastroenterology nursery. He resumed oral feeding on the sixth day of hospitalization.

Several exams failed to demonstrate a secondary cause to his arterial hypertension: adrenocorticotropic hormone $23.3 \mathrm{pg} / \mathrm{mL}$ (RR: 7.2 - 63.3), aldosterone 2.95 $\mathrm{ng} / \mathrm{dL}$ (RR: 1.00 - 16.0), free thyroxine $1.1 \mathrm{ng} / \mathrm{dL}$ (RR: 0.6 - 1.7), thyroid-stimulating hormone $1.93 \mu \mathrm{UI} / \mathrm{mL}$ (RR: 0.3 - 4.7), renin $0.5 \mathrm{pg} / \mathrm{mL}$, antinuclear and antiphospholipid antibodies were absent, C4 and C3 weren't consumed, plasmatic and urinary levels of vanillylmandelic acid, catecholamines and metanephrines were low. Thoracic and abdominal contrast enhanced computerized tomography and abdominal ultrasound with Doppler study did not show any signs of coarctation of the aorta, renal artery stenosis, structural abnormalities of kidneys, or tumours.

The investigation of a thrombophilic defect, done three months after the acute event, revealed a heterozygous G20210A prothrombin gene mutation. The remaining tests including protein $\mathrm{C}$, protein $\mathrm{S}$, activated protein $\mathrm{C}$ resistance, antithrombin, lupic anticoagulant and $F V$ Leiden mutation (G1291A) revealed no abnormalities.

Abdominal CT (10 days after admission) demonstrated a thickened pancreas in connection with inflammation and two small hypodense foci ( 9 and $6 \mathrm{~mm}$ ) in the anterior part of the pancreas body, translating small foci of necrosis. There were no other signs of local complications. The liver was slightly enlarged but with normal density and outline, without nodules.

\section{FOLLOW-UP AND OUTCOMES}

The patient was discharged on the fifteenth day. It was prescribed levetiracetam $3 \mathrm{~g} /$ day and clonidine $0.3 \mathrm{mg} /$ day. He had psychological support for the withdrawal of alcohol, tobacco and cannabis. The ambulatory blood pressure remained stable at $130 \mathrm{mmHg}$ systolic and $80 \mathrm{mmHg}$ diastolic. There were neither new seizures nor neurologic deficits. Clonidine was weaned off while perindopril $5 \mathrm{mg}$ was introduced.

The follow-up MRI, done two months later, revealed signs of reabsorption of the right frontal lobe haemorrhage and also complete disappearance of the subcortical white matter lesions, confirming the diagnosis of PRES (Fig. 3).

\section{DISCUSSION}

The PRES is an increasingly recognized and reported entity but its incidence is still unknown and the list of possible associated conditions is growing. To the extent of our knowledge, we report the ninth case of PRES described in the context of acute pancreatitis ${ }^{3-10}$ (six reported in the MEDLINE database)..$^{3-5,7-9}$ From the analysis of the previous clinical cases, five of the eight reported cases had at least one comorbid medical condition that has been implicated as a cause of PRES besides acute pancreatitis (AP). ${ }^{3-5,7-8}$ (Table 1) There are, however, three reports of AP due to

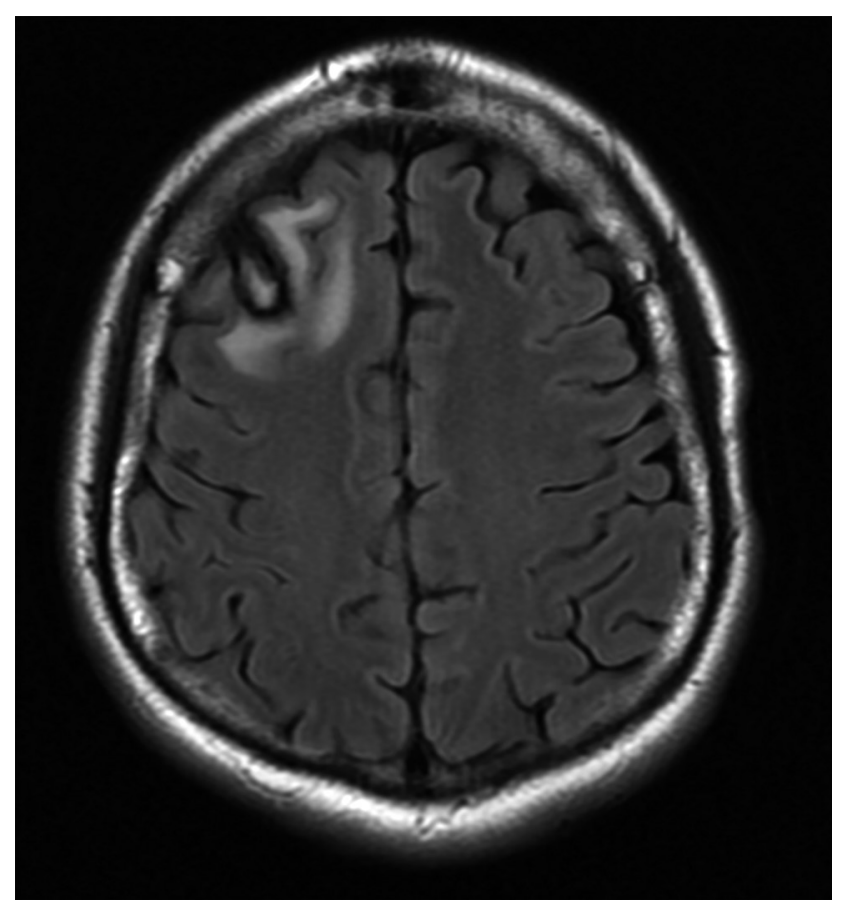

Figure 3 - Follow-up MRI scan (2 months). Axial T2-FLAIR images with complete reversal of the subcortical white matter changes and reabsorption of the lobar hematoma. 
Table 1 - Reported cases of simultaneous PRES and acute pancreatitis available at the date of submission

\begin{tabular}{|c|c|c|c|c|c|}
\hline $\begin{array}{l}\text { Year reported/ } \\
\text { reference }\end{array}$ & $\begin{array}{c}\text { Age } \\
\text { (years) / sex }\end{array}$ & $\begin{array}{l}\text { Diagnosis or condition } \\
\text { associated }\end{array}$ & Clinical findings & Lesions on $1^{\text {st }} \mathrm{MRI}$ & Follow-up MRI \\
\hline $2006^{3}$ & $23 / F$ & $\begin{array}{l}\text { Systemic lupus } \\
\text { erythematosus and } \\
\text { nephritis }\end{array}$ & $\begin{array}{l}\text { Headache, blurred } \\
\text { vision, confusion, } \\
\text { and focal seizures } \\
\text { that became } \\
\text { secondarily } \\
\text { generalized }\end{array}$ & $\begin{array}{l}\text { Bilateral T2 hyperintense } \\
\text { lesions in the } O \text { and } C \text { and in } \\
\text { the posterior limb of the right } \\
\text { internal capsule }\end{array}$ & 4 weeks: normal \\
\hline $2008^{4}$ & $60 / M$ & $\begin{array}{l}\text { Acute intermittent } \\
\text { porphyria }\end{array}$ & $\begin{array}{l}\text { Seizures, acute } \\
\text { confusion and } \\
\text { agitation }\end{array}$ & $\begin{array}{l}\text { Corticosubcortical } \mathrm{T} 2 \\
\text { hyperintense lesions in the } \\
\text { bilateral } \mathrm{Fr}, \mathrm{P} \text { and } \mathrm{O}\end{array}$ & 6 weeks: normal \\
\hline $2012^{5}$ & $13 / F$ & $\begin{array}{l}\text { Nephrotic syndrome } \\
\text { and hypertension }\end{array}$ & $\begin{array}{l}\text { Headache, visual } \\
\text { disturbance, } \\
\text { seizures }\end{array}$ & $\begin{array}{l}\text { Bilateral T2 hyperintense } \\
\text { lesions in the } \mathrm{P} \text { and } \mathrm{O}\end{array}$ & 2 months: norma \\
\hline $2013^{6}$ & $28 / F$ & Chronic alcoholism & $\begin{array}{l}\text { Seizure, confusion, } \\
\text { disorientation, visual } \\
\text { hallucinations, and } \\
\text { agitation }\end{array}$ & $\begin{array}{l}\text { Corticosubcortical T2 } \\
\text { hyperintense lesions in the } \\
\mathrm{P} \text { and } \mathrm{Fr} \text { (bilateral) and } \\
\text { subcortical lesions in the left } \\
\mathrm{O} \text { and } \mathrm{T}\end{array}$ & Day 16: normal \\
\hline $2014^{7}$ & $19 / F$ & $\begin{array}{l}\text { Phospholipid antibody } \\
\text { syndrome, acute } \\
\text { kidney injury and } \\
\text { hypertension }\end{array}$ & $\begin{array}{l}\text { Seizures and } \\
\text { headache }\end{array}$ & $\begin{array}{l}\text { Bilateral T2 hyperintense } \\
\text { lesions in the } \mathrm{C}, \mathrm{P} \text { and } \mathrm{Fr}\end{array}$ & $\begin{array}{l}\text { Normal (time } \\
\text { unspecified) }\end{array}$ \\
\hline $2014^{8}$ & $18 / M$ & $\begin{array}{l}\text { Monocytic leukaemia, } \\
\text { acute renal failure, } \\
\text { haemodialysis } \\
\text { and high-dose } \\
\text { methylprednisolone }\end{array}$ & $\begin{array}{l}\text { Generalized } \\
\text { seizures }\end{array}$ & $\begin{array}{l}\text { Bilateral T2 hyperintense } \\
\text { lesions in the subcortical and } \\
\text { deep white matter of the } T \\
\text { and } O\end{array}$ & $\begin{array}{l}\text { Day 42: } \\
\text { improvement }\end{array}$ \\
\hline $2015^{9}$ & $49 / M$ & Chronic alcoholism & $\begin{array}{l}\text { Confusion and } \\
\text { disorientation }\end{array}$ & $\begin{array}{l}\text { Corticosubcortical T2 } \\
\text { hyperintense lesions in both } \\
\text { the } \mathrm{P}, \mathrm{T} \text { and } \mathrm{O} \text {, and in the } \\
\text { left } \mathrm{C}\end{array}$ & $\begin{array}{l}1 \text { month: a few } \\
\text { microbleeds in } \\
\text { the left } C\end{array}$ \\
\hline $2015^{10}$ & $40 / F$ & Alcohol intake & Sudden visual loss & $\begin{array}{l}\text { Bilateral T2 hyperintense } \\
\text { lesions in the } \mathrm{P}, \mathrm{O} \text { and } \mathrm{C}\end{array}$ & No reference \\
\hline
\end{tabular}

M: Male; F: female; Fr: Frontal lobe; P: Parietal lobe; O: Occipital lobe; T: Temporal lobe; C: Cerebellum

alcohol consumption, without any other active comorbidity, that developed PRES.,, $9-10$

Our patient was severely hypertensive at presentation and the evolution of his hemodynamic profile revealed a hypertension difficult to control and the need for chronic medication after hospital discharge. Notwithstanding, we highlight that the symptoms of AP started before the symptomatology of PRES and we believe that the pro-inflammatory cytokines released contributed to its pathogenesis. There is a study in rats demonstrating that these cytokines (TNF and IL-6 released after AP) damage the blood-brain barrier (BBB) and are sufficient to cause leakage of blood to the cerebral tissue, causing vasogenic brain edema formation, as seen in PRES. ${ }^{11}$ In humans, the reports are yet scarce, but it seems that in most cases there is a need of an additional factor to cause PRES in acute pancreatitis cases (as demonstrated in Table 1). Another question to be answered in future reports is the relationship between the severity of pancreatitis and the possibility of developing PRES. In our case, the patient had a moderately severe to severe pancreatitis (depending on the classification used) but in most cases this data is not referred and there is insufficient data to classify.

There are also three reports of PRES in patients with acute alcohol withdrawal without other comorbidities reported and without any evidence of pancreatitis. ${ }^{12-14}$ In fact, an in vitro study has demonstrated that the oxidative stress resulting from alcohol metabolism in brain microvascular endothelial cells can lead to BBB breakdown in alcohol abuse, serving as an aggravating factor in neuroinflammatory disorders. ${ }^{15}$ We did not measure the serum level of ethanol, but the patient had recently consumed about $100 \mathrm{~g}$ of alcohol. The patient had no signs or symptoms of acute alcohol withdrawal but was medicated with benzodiazepines for control of his seizures and tiapride. One of these three cases reports the blood alcohol level which was very 
high $(358 \mathrm{mg} / \mathrm{dl})$. The other two make no reference to it, but the anecdotal association could mean that a very high level must be present for PRES to occur without any other predisposing factor.

To the extent of our knowledge, this is also the first documented case of PRES in a patient who is a heterozygous carrier of the G20210A prothrombin gene mutation. This mutation is an identified congenital risk factor for venous thrombosis but its role in arterial thrombosis is not clear. However, a relation to stroke in younger patients has been suggested. Since the prevalence of the mutation in the general population of southern Europe is about 3\%, and twice as high as the prevalence in northern Europe, it is not possible to make any casual or risk inference based in just this finding. Nevertheless, we highlight that one of the case reports of PRES in the context of acute pancreatitis occurred in a patient with phospholipid antibody syndrome. ${ }^{7}$ Therefore, the role of inherited or acquired thrombophilic defects in PRES needs to be further explored.

As other authors have previously suggested, ${ }^{5,9}$ we propose that acute pancreatitis might complicate, or even,

\section{REFERENCES}

1. Hinchey J, Chaves C, Appignani B, Breen J, Pao L, Wang A, et al. A reversible posterior leukoencephalopathy syndrome. N Engl J Med. 1996;334:494-500.

2. Staykov D, Schwab S. Posterior reversible encephalopathy syndrome. J Intensive Care Med. 2012;27:11-24.

3. Kur JK, Esdaile JM. Posterior reversible encephalopathy syndromean underrecognized manifestation of systemic lupus erythematosus. Rheumatol. 2006;33:2178-83.

4. Shen FC, Hsieh CH, Huang CR, Lui CC, Tai WC, Chuang YC. Acute intermittent porphyria presenting as acute pancreatitis and posterior reversible encephalopathy syndrome. Acta Neurol Taiwan. 2008;17:17783.

5. Yamada A, Atsumi M, Tashiro A, Hiraiwa T, Ueda N. Recurrent posterior reversible encephalopathy syndrome in nephrotic syndrome: case report and review of the literature. Clin Nephrol. 2012;78:406-11.

6. Ishikawa H, Natsume N, Matsui K, Tsuda H. Acute alcohol withdrawal accompanied by posterior reversible encephalopathy syndrome. Psychiatry Clin Neurosci. 2013;67:189.

7. Larmour K, Lewis G, Benson G, Hanko J. The challenges of antiphospholipid syndrome: experience from diagnosis to self-care. BMJ Case Rep. 2014;2014.

8. Nishimoto $M$, Koh $H$, Bingo $M$, Yoshida M, Nanno S, Hayashi $Y$, et al. Posterior reversible encephalopathy syndrome following acute pancreatitis during chemotherapy for acute monocytic leukemia. Rinsho cause PRES. The main pathogenic mechanism would be the damage of the blood-brain barrier by the pro-inflammatory cytokines released. Alcohol might be another important aggravating or causative factor.

\section{INFORMED CONSENT}

The patient provided written permission for publication of this case report. The CARE guidelines have been adopted for writing this case report.

\section{ACKNOWLEDGMENTS}

We would like to graciously acknowledge the revision work of Luís Jasmins.

\section{CONFLICTS OF INTEREST}

The authors declare that there are no conflicts of interest.

\section{FUNDING SOURCES}

No subsidies or grants contributed to this work.

Ketsueki. 2014;55:552-7.

9. Baek HS, Lee SJ. A case of posterior reversible encephalopathy syndrome associated with acute pancreatitis and chronic alcoholism. Gen Hosp Psychiatry. 2015;37:192.e3-5.

10. Murphy T, Sethi V, Al-Sharief K, Singh Ranger G. Posterior reversible encephalopathy syndrome (PRES) after acute pancreatitis. West $\mathrm{J}$ Emerg Med. 2015;16:1173-4.

11. Farkas G, Márton J, Nagy Z, Mándi Y, Takács T, Deli MA, et al. Experimental acute pancreatitis results in increased blood-brain barrier permeability in the rat: a potential role for tumor necrosis factor and interleukin 6. Neurosci Lett. 1998;242:147-50.

12. McKinney AM1, Short J, Truwit CL, McKinney ZJ, Kozak OS, SantaCruz $\mathrm{KS}$, et al. Posterior reversible encephalopathy syndrome: incidence of atypical regions of involvement and imaging findings. AJR Am J Roentgenol. 2007;189:904-12.

13. Bhagavati S, Choi J. Atypical cases of posterior reversible encephalopathy syndrome. Clinical and MRI features. Cerebrovasc Dis. 2008;26:564-6.

14. Kimura R, Yanagida M, Kugo A, Taguchi S, Matsunaga H. Posterior reversible encephalopathy syndrome in chronic alcoholism with acute psychiatric symptoms. Gen Hosp Psychiatry. 2010;32:447.e3-5.

15. Haorah J, Knipe B, Leibhart J, Ghorpade A, Persidsky Y. Alcoholinduced oxidative stress in brain endothelial cells causes blood-brain barrier dysfunction. J Leukoc Biol. 2005;78:1223-32. 